\title{
Gastrointestinal helminths in migratory Camel
}

\author{
S.G. Rewatkar ${ }^{1}$, S.S. Deshmukh ${ }^{1}$, S.K.Deshkar ${ }^{1}$, D.K. Maske ${ }^{4}$,P.D. Jumde ${ }^{1}$ and G.N. Bhangale ${ }^{1}$ \\ Department of Veterinary Parasitology, \\ Nagpur Veterinary College, MAFSU,Nagpur - 440006, \\ rewatkarswap2006@yahoo.com. Mob. No.: +91-9860024372.
}

\begin{abstract}
Survey of gastrointestinal helminth parasites in camel migrated from U.P., M.P., and Rajasthan at Nagpur region was carried out in early summer, 2008. Total 28 samples (12 males and 16 females) were collected from different places of Nagpur region. They revealed parasites as Trichuris sp.(50\%), Strongyloides sp.(32.14\%), Trichostrongylus sp.(10.71\%), Nematodirus sp.(10.71\%), Haemonchus sp.(14.28\%), Eurytremasp.(21.42\%), Eimeria sp.(25\%), Entamoeba sp.(17.85\%) and Balantidium sp.(7.14\%).All were found positive for mixed helminthic infection.
\end{abstract}

Keywords: Gastrointestinal helminths, Camel, Faecal sample, Migratory.

\section{I ntroduction}

Camels are generally infected with numerous parasites. Parasitic infection cause considerable losses to our ship of deserts (camel). Numbers of parasites are responsible for enteric infections in camels (Wahba, et al., 2003). Heavy helminthic infection causes significant impact in these animals resulting into high morbidity and mortality. In order to understand the severity of helminth parasites in camel especially migrated from different places to Nagpur region, a survey was carried out in early summer of the year 2008 and the observations are reported in this paper.

\section{Materials and Methods}

Total 28 camels of both sexes, age ranging 3 to 18 years belonging to villages of district Wardha and Nagpur were examined. Faecal samples were collected in sterilised glass bottles, transported to laboratory, processed and examined microscopically by adopting standard procedure. The ova were identified based on morphological characters as described by Soulsby (1982), Sloss et al., (1994).

\section{Results and Discussion}

All 28 samples examined were found positive for mixed helminthic infection. The larvae and eggs found were of Trichuris sp. (50\%), Strongyloides sp. (32.14\%), Trichostrongylus sp. (10.71\%), Nematodirus sp. (10.71\%), Haemonchus sp. (14.28\%), Eurytrema sp. (21.42\%), Eimeria sp. (25\%), Entamoeba sp. (17.85\%) and Balantidium sp. (7.14\%).

It may be obligatory to mention that since camel are important for transportation and agriculture in desert and dry region the faecal examination and deworming should be done regularly, in addition to supplementation of clean food and drinking water to animals.

\section{References}

1. Sloss M.W., R. L. Kemp, A. M. Zajac (1994): Veterinary Clinical Parasitology. $6^{\text {th }}$ edition.

2. Soulsby E.J.L. (1968): Helminths, Arthropods and Protozoa of domesticated Animals. $7^{\text {th }}$ edition Baillier Thindall, London.

3. Wahba A.A., E.L. Refail M.A.H. (2003): Detection and Identification of enteric parasite infesting camel. Egyptian Journal of Agricultural research. 81(1): 297310.

Table-1. I ncidence of Helminth parasites in Camel.

\begin{tabular}{|c|l|c|c|c|}
\hline Sr. no. & Parasites & Total samples & Samples of mixed infection & Percentage \\
\hline 1 & Trichuris sp. & 28 & 14 & $50 \%$ \\
2 & Strongyloides sp. & 28 & 9 & $32.14 \%$ \\
3 & Trichostrongyle sp. & 28 & 3 & $10.71 \%$ \\
4 & Haemonchus sp. & 28 & 4 & $14.28 \%$ \\
5 & Nematodirus sp. & 28 & 3 & $10.71 \%$ \\
6 & Eurytrema sp. & 28 & 7 & $21.42 \%$ \\
7 & Eimeria sp. & 28 & 5 & $25 \%$ \\
8 & Entamoeba sp. & 28 & 2 & $17.85 \%$ \\
9 & Balantidiam sp. & 28 & $7.14 \%$ \\
\hline
\end{tabular}

\begin{tabular}{cll}
\hline 1. M.V.Sc. Scholar, & 2. Professor and Head & \\
\hline www.veterinaryworld.org & Veterinary World Vol.2, No.7, July 2009
\end{tabular}

